\title{
Farmers Adapt to Climate Change Irrespective of Stated Belief in Climate Change or Farm Advisor Reinforcement of (Dis)belief: A Case Study in Northern California
}

\author{
Margiana Petersen-Rockney ( $\sim$ margiana@berkeley.edu ) \\ University of California Berkeley https://orcid.org/0000-0003-3126-786X
}

\section{Research Article}

Keywords: Climate change belief, agriculture, adoption gap, adaptation, mitigation, farm advisors

Posted Date: January 28th, 2022

DOI: https://doi.org/10.21203/rs.3.rs-1281622/v1

License: (9) This work is licensed under a Creative Commons Attribution 4.0 International License. Read Full License 


\section{Abstract}

Farmers are front line workers in the climate crisis. As in many parts of the world, climate change impacts like droughts and wildfires are becoming everyday experiences that natural resource-dependent communities must grapple with. This article draws on ethnographic methods, including over 100 interviews with crop and livestock farmers and institutional actors, to query climate change experience, belief, and response in Siskiyou County in rural northeastern California. I find that farmers recognize and describe changes in climate that align with meteorologic evidence of climate signals emerging above the noise of weather variability. Farmers often chronicle these changes in terms of weather cycles and harsh geographies. Local public farm advisors, like Cooperative Extension Advisors and USDA staff, echo these beliefs, which builds rapport with many farmers, while hindering the development of programming, including potential climate-related technical and financial assistance available to a broader set of farmers. Farmers respond to climate change impacts with a range of adaptations, irrespective of their stated belief in climate science. Findings bolster growing evidence that climate change belief and action are not tightly coupled, supporting efforts to retire the currently dominant knowledge-deficit paradigm of farmer climate change programming. Rather than focusing on trying to convince farmers of climate science - or even convince farm advisors themselves - this study suggests that more culturally appropriate interventions that skip belief and focus on action and outcomes could be more effective in increasing the pace and scale of farmer climate action.

\section{Research Highlights}

- Farmers recognize and describe changes in climate over time, discussing these changes in terms of their own lived experience, weather variability, ongoing cycles, and harsh geographies.

- Farmers' perceptions align with meteorologic evidence of substantial natural variability in the region, as well as increasingly strong climate change signals.

- Though experiences of severe weather events did not change climate change belief, these experiences did catalyze changes in farm practices and livelihood strategies.

- In response to climate change impacts, farmers adopted a range of short and long term field management practices and livelihood strategies, irrespective of stated belief in anthropogenic climate change.

- Livelihood adaptations include a transition to off-farm work as permanent and leaving agriculture, presenting added climate change induced barriers to generational transfer.

- Proximate farmer motivation, such as economic efficiency and conservation stewardship, can be understood as expressions of meta-motivations of control and identify values.

- Public farm advisors (e.g. local level Cooperative Extension and USDA staff) often reinforce dominant farmer beliefs related to climate-change, explicitly by reiterating those perceptions or implicitly by avoiding the topic entirely. 


\section{Introduction}

\subsection{Introduction: Farmers and climate change}

Farmers and ranchers have long managed environmental uncertainty (Brunson and Huntsinger 2008; Coles and Scott 2009), but they are now on the front lines of climate change-induced stressors (eg. rising temperatures), shifts (eg. earlier snowmelt), and shocks (eg. more intense and frequent wildfires). Today, climate change is occurring at a rate and scale at the upper bounds of many modeled predictions (IPCC 2021) and well beyond the noise of weather variability farmers have experience coping with (Pathak et al. 2018; Azadi, Yazdanpanah, and Mahmoudi 2019). Physical climate change impacts compound the portfolio of non-climate risks (Meraner and Finger 2019; Karki, Burton, and Mackey 2020) farmers already face stemming from corporate concentration (Howard 2016), globalization (Liverman 2015), and unequal market access (Morton 2007).

Crises demand responses. The decisions that farmers make in response to global crises like climate change are crucial to maintaining rural economies, food security, open spaces, and biodiversity (Kremen and Merenlender 2018). Agriculture, in its dominant highly simplified form, is a significant cause of climate change, responsible for an estimated $23 \%$ of global greenhouse gas emissions (Shukla et al 2019). Agricultural working landscapes have the potential to simultaneously enhance adaptive capacity and mitigate emissions, especially when diversifying strategies are adopted (Kremen and Miles 2012). For example, field practices that increase soil organic matter can facilitate adaptation to precipitation variability by increasing the soil's ability to hold moisture, while also sequestering carbon (Gosnell, Charnley, and Stanley 2020). How farmers respond to climate change determines not only current resilience and mitigation, but also shapes future adaptive capacity (Wyborn et al. 2015; Petersen-Rockney et al. 2021).

Yet there is a wide gap between scientific understanding of climate change adaptation and mitigation and the adoption of these management practices by U.S. farmers. U.S. farmers consistently express limited belief in climate change's anthropogenic origins (Prokopy et al. 2015). Many farmers suggest that climate change is not a significant local risk to their farms (Stuart, Schewe, and McDermott 2012) and describe limited interest in implementing adaptation or mitigation management practices (Lin 2011; Davidson 2016; Schewe and Stuart 2017). Many farm advisors, in turn, either share these perceptions, or are so concerned that climate change will alienate their clientele that they avoid the topic (Grantham et al. 2017; Schattman et al. 2018; Wiener et al. 2020).

New policies and programs that increase the pace and scale of climate change adaptation and mitigation are urgently needed (Findlater et al. 2018). Many efforts to date, born out of theoretical and empirical research suggesting farmers' beliefs and actions regarding climate change are tightly coupled (e.g. Arbuckle et al. 2013; Chatrchyan et al. 2017; Le Dang et al. 2014), have focused on educating farmers about climate science, adhering to the (much-critiqued) "knowledge-deficit model" (Jasanoff 2003; McNeil 2013). This uni-directional knowledge transfer paradigm has not led to meaningful changes in 
land management practices, leaving scholars concerned about agriculture's ability to meet its mitigation and adaptation potential (Schewe and Stuart 2017; Inman et al. 2018; Davidson et al. 2019). To adapt to climate change effectively and equitably, researchers and policy makers must develop place-based strategies (Rojas-Downing et al. 2017) and include farmers' experiences and beliefs in adaptation discourse (Soubry, Sherren, and Thornton 2020). Therefore, researchers must try to understand how farmers, and the institutional advisors charged with supporting them, are experiencing climate change.

This study draws on mixed methods, including 108 in-depth interviews with farmers and institutional actors in northeastern California, to broaden understandings of farmers' own perceptions of climate change impacts, explanations, and responses. I employ an identity theory framework to link individual, social, and institutional constructions of experience (Burke and Stets 2009). I focus on adaptation action because they are often adopted before mitigation practices (Arbuckle et al. 2013), decision making around adoption is more locally influenced than decision making around mitigation (Haden et al. 2012), and many adaptation practices offer mitigation co-benefits (Gosnell, Charnley, and Stanley 2020; Findlater et al. 2018). I show that farmers in this region are changing their farming practices and livelihood strategies in response to climate change, irrespective of their beliefs about climate change. I argue that belief and action are largely decoupled in this context. Taking farmers' experiences and perceptions as serious contributions to the discourse suggests that it is time to break from older knowledge-deficit models. Instead, my findings suggest that focusing on broad meta-motivations, particularly farmers' desire to have greater control and flexibility over their means of production, may yield greater efficacy to overcome the adoption gap.

Siskiyou County in northeastern California provides an ideal case study to examine these questions. California is already experiencing severe climate change impacts, including record-setting heatwaves, droughts, and wildfires (Bedsworth et al. 2018; Higuera and Abatzoglou 2020) that are negatively impacting agriculture (Pathak et al. 2018) and are projected to intensify (Karki et al. 2019). The northeastern part of the state is especially well suited for analyzing farmers' climate change perceptions. Ranchers especially in this largely snow- and rain-fed system are increasingly vulnerable to droughts and fires with fewer infrastructural and state resources to buffer climate change impacts, relative to largescale crop farmers in California's Central Valley. Unlike much of the state's highly corporatized agriculture (Walker 2004), most farms in this region operate primarily with family labor (Lobao and Meyer 2001), and may therefore perceive themselves to possess more decision-making agency (Price and Leviston 2014). Like many farmers in the Western U.S. (Yung et al. 2015), farmers in the Siskiyou region are politically polarized with strong conservative and anti-government ideologies, which are consistently the strongest predictors of farmers' perceptions of climate change risks (Safi, Smith, and Liu 2012) and beliefs (Hornsey, Harris, and Fielding 2018; Liu, Smith, and Safi 2014).

\section{Methods}

\subsection{Study site}


Over three years (2017-2020) I employed mixed, primarily qualitative methods, in an extended case study (Burawoy 1998) of farmers and institutional actors in Siskiyou County, California. Ecologically, this region is an extension of the Great Basin and range system, marked by agricultural valleys surrounded by high desert mountains. Socio-culturally, Siskiyou County is, relative to the rest of California, more rural, economically marginalized, and politically conservative (Fig. 1). Conducting research within the spatial boundary of a county allowed me to examine local governance and institutional responses to climate change.

Siskiyou County's weather is subject to substantial natural variability, particularly fluctuations in temperature and relative dryness (Fig. 2), which make climate change effects difficult to identify at a fine grain and scale. Climate signals are, however, emerging. Commensurate with broader findings that heat wave intensity and frequency are increasing across Western North America (IPCC 2021, hexagon plot in SPM), long-term trends in summer heat (Fig. 2, blue line) indicate an increase in maximum temperatures over the past 70 years in Siskiyou County.

Today, Siskiyou County is home to a diverse mix of farms in terms of products, size, and structure. Compared to the rest of California, farms in Siskiyou are more often mid-size and family-operated, with half of farm operators reporting farming as their primary occupation (USDA Census 2017). While cowcalf and forage crops remain culturally dominant, farmers raise a wide variety of livestock and grow many different crops. Like farmers in other rural U.S. regions (Singh, Eanes, and Prokopy 2020), many residents self-identify as conservative and describe climate change as politically polarizing.

I employed primarily ethnographic methods to elucidate attitudes, beliefs, and conceptual understandings of climate change. Qualitative methods are especially well-suited to investigating the nuances of politically polarizing topics like climate change (Takahashi et al. 2016). By working in the region for an extended period of time, I was able to take account of changing social and ecological dynamics through periods of change and crisis (Findlater et al. 2018).

\subsection{Data collection and analysis}

I employed a purposive sampling frame (Yung and Belsky 2007) to include maximum variation in farm and farmer characteristics (Buttel and Newby 1980; Prokopy et al. 2008), as well as key informants. Informants were contacted via a snowball sampling and network recruitment method (Parker, Scott, and Geddes 2019). I conducted 108 semi-structured interviews with crop and livestock farmers $(n=76)$ and institutional $(n=32)$. Semi-structured interview questions queried respondents' experiences of change in temperature, dryness, and other weather and climate impacts, as well as their beliefs about these experiences, actions taken in response, and social network connections. Interviews were primarily conducted at the informant's site of work, such as farm fields and public offices. Interviews typically lasted between one and four hours. Ninety interviews were audio-recorded and 18 informants preferred only written notes be recorded. Farmer interviews included a baseline survey of demographic information and farm management practices, including farm practices in use, at what spatial and temporal scale, and motivations for adoption. 
I also engaged in participant observation (Geertz 2005), including assisting farmers in everyday tasks and attending local events to understand broader community dynamics and experiences at the intersection of belief and action. Additionally, I conducted a livelihood analysis with six farming families in which I interviewed multiple members of the family over several years to gain a deeper understanding of intrahousehold dynamics and responses to evolving social and ecological conditions. I transcribed qualitative data using Trint software and hand transcription. I then coded data in MaxQDA using a grounded theory approach (Thornberg and Charmaz 2013) and a mix of semantic and latent codes both emergent from the data and derived from the literature (Schewe and Stuart 2017).

Drawing on quantitative data - including the USDA census, meteorological data, and regional climate models - allowed me to triangulate and extend my findings. Drought data (Fig. 1) was derived from the Palmer Drought Severity Index, which estimates relative dryness on a regional average over a 2.5 degree $\mathrm{x}$ 2.5 degree domain centered on $(41.25,-121.25)$ from monthly precipitation and temperature data collected from 1950-2015 (PDSI). The summer average (Fig. 1) of the daily maximum temperature data is from the Yreka weather station in the center of Siskiyou County (NOAA Climate Data). Annual average temperatures in Siskiyou County (Fig. 2) were derived from Cal-Adapt using Gridded Historical Observed Meteorological Data (University of Colorado, Boulder) for observed data, and LOCA Downscaled Climate Projections (Scripps Institution of Oceanography) for modeled data of an average simulation (CanESM2) in an optimistic scenario (RCP 4.5) in which emissions peak in 2040 and then decline. This research received university IRB approval (Protocol \#2018-04-11036).

\section{Theory}

Climate change is broad and nebulous - both spatially and temporally - making pinpointing the experience of its cascading impacts difficult (Breakwell 2010). On the ground in a farmer's field, it can be difficult to distinguish the noise of weather variability and the signal of broader climate change (IPCC 2021). The climate is, however, changing rapidly (Ibid). Adaptation is the response to that change, which includes adjustments to actual and expected climate effects (IPCC 2014). Adaptation actions range from coping with change, to incremental adjustments, to system transformation (Chhetri, Stuhlmacher, and Ishtiaque 2019). Many adaptation field management practices, especially those that employ agroecological principles, also offer mitigation co-benefits by sequestering carbon (Davidson 2019; Lin 2011).

The literature on farmer decision-making has primarily focused on the adoption of best management practices defined in terms of yield and conservation outcomes (Prokopy et al. 2019; Schewe and Stuart 2017). Much research continues to assume, explicitly or implicitly, that farmers are individual economically rational actors, despite evidence otherwise (Hyland et al. 2016; Findlater 2018). The Theory of Planned Behavior (Ajzen 1991), for example, is often used to predict farmer behavior based on characteristics of the farm (eg. acreage or crop type) or farmer (eg. experience or age), neither of which provide consistent explanatory power for farmer decision making (Prokopy et al. 2019; 2008). 
The pace and scale of climate action is highly dependent on culture, ethics, perceptions, and beliefs (Marlon et al. 2019). Cognitive factors - like beliefs and perceived agency - significantly shape farmer decision making (Takahashi 2019), leading to a growing emphasis on the relationship between beliefs, attitudes, and attitudes toward climate change (Findlater 2018). Identity theory offers a lens through which to understand the social construction of these cognitive factors that shape farmers' frames of reference through their role in society, group interactions, and institutional engagement (Burke and Stets 2009). Understanding farmers' identity as co-constructed with a situated cultural context creates new opportunities wherein stakeholders - including farmers, researchers, and policy makers - can link individual and structural decision making factors (Coughenour 2003; McGuire, Morton, and Cast 2013).

Studies of farmers' decision making regarding climate change have largely focused on farmers' beliefs. Beliefs about climate change include the extent to which individuals believe in climate change's occurrence, anthropogenic causes, and related phenomena (Hyland et al. 2016; Le Dang et al. 2014). Climate change belief is often characterized as the greatest motivator of adaptation response (Nguyen et al. 2016). Beliefs about climate change influence farmers' perception of the physical (Menapace, Colson, and Raffaelli 2015), policy (Niles, Lubell, and Haden 2013), and social risks of climate change. Belief in anthropogenic climate change is often characterized as the best predictor of farmers' action on climate change (Arbuckle 2013; Le Dang et al. 2014; Roesch-McNally et al. 2017), or as a prerequisite for farmers to implement climate change related management practices (Sulewski and Kłoczko-Gajewska 2014; Chatrchyan et al. 2017).

The relationship between climate change experience and belief is co-constitutive. Experiences of severe weather can ground climate change's abstract nature, making it more proximate and believable (Azadi, Yazdanpanah, and Mahmoudi 2019). Personal experiences with severe weather events - one's own, or agricultural peers' (Carrico et al. 2015) - positively influences farmers' beliefs in climate science and willingness to implement adaptation or mitigation practices (Niles and Mueller 2016; Safi, Smith, and Liu 2012; Coles and Scott 2009; Niles, Lubell, and Brown 2015). Belief or disbelief in anthropogenic climate change can also shape experiences of weather. For example, farmers and ranchers in Nevada who believed in anthropogenic climate change perceived greater risks to their operation from future impacts than did those who said that they did not believe in climate change's anthropogenic origins (Saleh Safi, James Smith, and Liu 2012).

Yet the connection between farmers' experience, belief, and decision-making regarding climate change remains complex (Schattman, Conner, and Méndez 2016; Findlater, Satterfield, and Kandlikar 2019). Unusually favorable weather can reduce the salience of weather risks and adaptation action (Findlater, Satterfield, and Kandlikar 2019). Likewise, past experiences with unusually bad weather, especially in regions known for their harsh climate, can normalize potential future extremes, incentivizing farmers to hedge their bets each year and manage "well enough" instead of adopting proactive adaptation strategies (Takahashi, Mano, and Otsuka 2019; White and Selfa 2013). The accelerating pace and scale of climate change impacts - including novel megafires and megadroughts - may also limit farmers' ability to rely on previous climate experiences (Takahashi, Mano, and Otsuka 2019). 
Importantly, physical impacts, like droughts and heatwaves, are not the only effects of climate change that farmers experience. People's cultural experiences of climate change, for example through media exposure (Findlater et al. 2019) and political affiliation (Dunlap, McCright, and Yarosh 2016), strongly influences climate change beliefs. In the U.S., climate change has been made into a politically divisive issue (Kahan 2012) associated with progressive politics and environmental groups (Sing et al. 2020), in which U.S. farmers express limited trust (Linda Stalker Prokopy et al. 2015). Additionally, experiences not directly related to farming, like social interactions (Knapp and Fernandez-Gimenez 2009) and selfperceptions (L. W. Morton, McGuire, and Cast 2017), shape farmers' beliefs about climate change and its origins (Sing et al. 2020), as well as perceptions of its impacts and appropriate responses (Karki, Burton, and Mackey 2020).

Despite general skepticism of climate change science, farmers are adopting new practices and strategies in response to the impacts of climate change. Farmers in dry regions prepare for droughts irrespective of their climate change beliefs (Coles and Scott 2009). In California's Central Valley, for example, farmers who experienced water shortages adopted more efficient irrigation practices in response (Haden et al. 2012). Beef and grain farmers in Alberta, Canada adopted field management practices with climatemitigation benefits while high rates of climate skepticism persisted (Davidson 2019). Similarly, farmers in New York (Takahashi et al. 2016), ranchers in Montana (Yung et al. 2015), dairy farmers in Wisconsin, and oyster farmers in New England (De Master et al. 2019), have implemented new management strategies in response to severe weather events, despite varied willingness to attribute these impacts to climate change. As climate science, discourse, and impacts continue to evolve in farmers' daily lived experience, growing evidence suggests that stated belief in anthropogenic climate change may not be as crucial for farmers to implement climate change related management practices as previously thought.

Farm advisors - including Cooperative Extension, Farm Service Agency, and Natural Resources Conservation Service staff - may play a crucial role in farmers' responses to climate change. As intermediaries between farmers and researchers, public farm advisors are important sources of information both directly for farmers (Arbuckle et al. 2013; Prokopy et al. 2015) and for the private industry actors who farmers often preferentially trust as information sources (Arbuckle, Morton, and Hobbs 2015). Public farm advisors also provide financial resources, including administering disaster relief programs, which are crucial in shaping the structural constraints farmers experience when taking climate action, including limited resource access (Ranjan et al. 2019; Knapp and Fernandez-Gimenez 2009), insecure land tenure (Inman et al. 2018), and contract lock-in (Schewe and Stuart 2017). Importantly, institutional norms and discourses help shape whether and how farmers respond to change (Davidson 2016). Farm advisors often share similar cultural values and political ideology with the farmers they work with (Wojcik et al. 2014; Prokopy et al. 2015; Schattman et al. 2018). Interacting frequently with farmers on the ground, these public institutional staff have an important role to play in increasing the pace and scale of farmers' climate action (Wojcik et al. 2014; Haigh et al. 2015; Church et al. 2018; Niles et al. 2019), yet few choose to discuss or engage meaningfully with climate change in their work (Grantham et al. 2017; Wiener et al. 2020). 
To better understand farmers' experiences, beliefs, and responses to climate change, and the role of public actors who work with farmers in shaping these factors, I ask: How do agricultural actors in Siskiyou County perceive their interactions with the impacts of climate change, and how do they respond? Further, how do public farm service providers engage with farmers' climate related attitudes and practices, and how can these public actors working in a climate science skeptical context nevertheless help farmers adapt?

\section{Results And Discussion}

\subsection{Farmers experience, recognize, and describe climate trends amidst weather variability}

Nearly every farmer I interviewed reported weather change over time. Many distinguish climate signals rising above the noise of weather variability by noting, for example, warmer winter temperatures and snowpack reductions - signals that, under projected climate scenarios, will emerge more strongly and increase the severity of extremes in Siskiyou County (Fig. 2). Speaking of winter minimum temperatures and snowfall, one farmer in his 60 s said, "The trend is it has been lighter and lighter winters. Now, we're lucky if we get six to eight inches that'll stick around for more than three or four days at a time... The winters have become much more mild" (\#63).

Farmers also described a shift in the duration and intensity of droughts from bounded shocks to constant stressors. Echoing a common sense of this change, a cattle rancher said of droughts in decades past, “They just didn't seem to last very long. You'd have a [dry] summer. But it just didn't seem to go on and on and on and on. This is very different... we had a bad year and then the next year is worse, and we had a bad year, and then the next year is worse...I mean, that's bad... it's like, man, this is really discouraging" (\#41).

Warmer, dryer conditions have increased agriculture's vulnerability to wildfire and smoke. Since 2018, catastrophic wildfires in California -- including the 2021 River Complex fire in Siskiyou County, one of the largest fires ever recorded in the state (CalFire 2021) -- have produced smoke that blankets the area for weeks each summer and fall. "We just got smoked in real bad," one farmer said, describing how, "The grass just didn't grow like it usually does. Neither does the hay. It slowed things down... Much lighter gain and the cows didn't look as good going into the winter" (\#69). As one county Agricultural Commissioner summarized, "The situation is different, smoke and drought are out of control." Additionally, some farmers noted greater winds associated with warming. One said, "We get so windy that there's so much more evaporation" (\#106).

Farmers often described changes by comparing current farming practices or landscape features to those of the past. Like many older farmers, a retired cattle and hay farmer compared today's conditions to those of his childhood in the 1950s and 1960s by saying, "You could grow usually a pretty good dry land crop, just off of snowmelt, just off the thunderstorms in the summer... now it's noticeably drier. We used to have 
two, three feet of snow on a pretty regular basis in the wintertime... When I was a kid this whole mountain range here in the springtime, the snow would melt and we'd have water running down sloughs or low spots out to the fields. There was a shallow lake, and it would freeze and we'd go there ice skating. I probably haven't seen water in there for 30 years now" (\#43). Many farmers from the region described a reduction in snowfall and snowpack over their lifetimes consistent with meteorological observations and climate models (Fig. 2). Farmers often described these memories of a different climate in relation to farm tasks that they used to perform - like regularly digging out snow to feed livestock and carrying feed by sled in winter. Farmers also observed changes in the broader ecology of their farm landscapes, particularly in wildlife migrations, abundance, and winter survival.

These results indicate that farmers in this region a) acknowledge that the climate is different now than it was in the past, b), describe the same trends observed by climate scientists, including distinguishing between short-term weather variability and long-term shifts in climate, and c) discuss those differences in terms of their lived experience of weather. These observations are consistent with other studies, which find that farmer perception of temperature changes tend to align with meteorological data (Foguesatto et al. 2020) and climate science literature (Mccollum et al. 2017). These data also bolster scholarship suggesting that weather may be a poor proxy for climate (Liu, Smith, and Safi 2014; Findlater et al. 2019). I found little evidence, however, that farmers' experiences of physical climate change increased their belief in its anthropogenic causes.

\subsection{Farmers discuss changes in terms of weather, ongoing cycles, and harsh geography}

Farmers, across farm types and farmer characteristics, discussed the changes they observed in terms of weather, not climate. Doing so allowed farmers to hold simultaneous mental models of both changing patterns and random weather events. A typical older cattle and hay farmer said, "Weather pattern has changed. We have much milder winters. I don't know, I don't feel that the temperature fluctuation has been extreme. Some summers are warmer. Some are cooler. Just quite a bit less moisture" (\#43). Another crop and cattle farmer described milder winters, adding, "Individual weather events, they're just pretty much random" (\#44).

When asked about climate change, the majority of farmers, across farm types and farmer characteristics, expressed disbelief in anthropogenic climate change. Most responded that weather is cyclical, offering comments like, "Things are always changing in cycles" (\#12) and "Droughts are always cyclical" (\#70). Some farmers recounted specific cycles of dry or wet weather through multigenerational family histories.

A diversified multigenerational farmer, for example, described family journals that detailed "the river going dry in the 1880s for an extended period of time where they drove wagons down the riverbed every day because there was no water." An alfalfa farmer in his 20 s told me how his parent's generation described an oscillating pattern of wet and dry cycles back to their childhoods in the 1950's, "It just comes in waves... for guys that have been here for 40 years you see a lot of patterns" (\#12). 
Despite remaining unconvinced by climate science of the modern era and describing weather cycles as natural, farmers often acknowledged that weather patterns have fundamentally changed in their lifetimes and some explicitly acknowledged paleoclimate science. A cattle rancher told me, "The climate has, is, changing. Just look at history, right? Climate changes over the eons of centuries. We go through cycles and I think we're in a dryer cycle is what it boils down to... I know what the scientists say, global warming and the ice packs are melting and doomsday is ahead of us. But I don't necessarily buy into that so much. But I will admit that, yeah, the climate has changed. We are in a dryer cycle right now" (\#63). One illustrative forage farmer explained, "You're seeing drought cycles that are changing from what we were used to in the 70s, 80s, 90s. Now, it's been dry, you can see a whole cycle has changed" (\#36).

Some farmers normalized the extreme changes they experienced in terms of agriculture's exceptional vulnerability to weather and the region's high degree of weather variability. Asked about changes in precipitation and temperature, a sheep farmer said typically, "Everything changes when you live on a farm. You get up in the morning and you don't know what's going to happen. You have no idea. You get to expect the unexpected" (\#15). Consistent with the region's high weather variability (Fig. 2), most farmers noted the harshness of their geography. A mixed vegetable farmer said, for example, "So the climate change, I mean our area is so drastic all the time... it's extremely wet, extremely dry, extremely hot, extremely cold" (\#106). Farmers often shared specific examples of extreme or "bizarre weather events" (\#42) they had experienced, like snow on the 4th of July and Memorial Day, as evidence of the general unpredictability of weather in the region. One farmer said, "It's all normal here" (\#12), and another described the harsh climate as "a mother nature thing" (\#16). Others noted the "pretty short growing window" (\#63) that limits what crops they can grow "because it gets so cold" (\#56) and "goes from cold and wet to hot and dry too quick" (\#48).

It is worth noting that while the majority of farmers said that they did not believe in anthropogenic climate change, a small minority did. A young orchardist said, "I believe in climate change, it's ok" (\#115). A multispecies rancher told me, "I think you would be silly to not admit it. I think you're watching one news channel too much... I mean, like it or not it's definitely our climate's different than the way it was 20 years ago" (\#21). These private admissions - almost all by diversified farmers who sold their products through the same direct-market channels - were often accompanied by requests not to be identified within the wider community as deviating from normative disbelief in anthropogenic climate change. This finding suggests the importance of social group affinity in shaping farmers' experiences of climate change. These farmers were adept at navigating differing social norms within distinct farming groups - sharing climate change belief with some and following broader social norms of discussing changes in terms of cycles and harsh geographies with others.

Findings that most farmers in this region attribute drought to natural cycles and express skepticism in anthropogenic climate change are consistent with previous studies (Yung et al. 2015; Liu et al. 2014). Divergent from previous conclusions that belief in natural cycles both reduces ranchers' sense of agency to act and facilitates optimism that a cyclically changing climate will return to normal (Yung et al. 2015), I 
find that many farmers believe that climate change is cyclical, while also asserting concerns that those cycles will get worse.

Farmers hold diverse and dynamic identities and motivations (Hyland et al. 2016), as well as understandings of their experiences with weather and climate. Different farmers can hold multiple interpretations and narratives of shared experiences, as some farmers assigned drought to climate change and others did not. Individual farmers can also hold simultaneous mental models - as many did in this study - of both changing weather cycles and naturally random events. Ambiguity, and the multiple interpretations it allows at the community and individual levels, provides opportunities for convergent action for divergent reasons (Eisenberg 1984; Davenport and Leitch 2005). If farmers reduce their water use in the face of drought, does it matter if some did so to save money on electricity, some did so to keep more water in their soil, and some did so because they believe in climate change?

4.3 Farmers respond to climate change impacts with a range of adaptations, irrespective of stated belief in anthropogenic climate change

Every farmer in this study - irrespective of their climate change beliefs or perceptions - changed how they farmed in response to the impacts of climate change. Farmers especially described droughts as "wake up calls" (\#29) or "turning points" (\#102) that spurred them to adapt. As a typical livestock farmer observed, "The drought has kind of shaken people up, saying OK this is not a guarantee" (\#119). In response to the impacts of climate change, farmers invested in infrastructure, changed their field management practices, and transformed their livelihood strategies.

Nearly all farmers in this study were investing in new infrastructure and technology. As surface water sources were becoming more precarious - ecologically and politically - farmers were reducing water use, increasing water storage capacity, and favoring groundwater sources. For example, many of the larger acreage farms had already, or were in the process of, replacing wheel lines with center pivots with Natural Resources Conservation Service funding assistance. Speaking of 2018, a young alfalfa farmer said, "That's one thing I learned, it costs more money but you've got to try to take mother nature out of the factor as much as you can, whether it's deepening your wells or having storage ponds or something" (\#19). About half the farmers I interviewed reported trying water monitoring technologies like soil moisture probes or crop monitoring software, but with mixed results and enthusiasm. Several echoed the sentiment of one crop farmer who said these technologies "didn't tell us anything we didn't already know" (\#61). Some farmers recognized that input-oriented infrastructure improvements - such as digging wells, pivot irrigation, and monitoring software - were temporary solutions to drought. But these were the response options most available and encouraged, even funded, by experts like Natural Resources Conservation Service staff.

In addition to infrastructure investments, most farmers were also changing how they farmed. Many expressed their intent to scale up or adopt field management practices that would help reduce their reliance on inputs over the long-term. Farmers described how building soil organic matter became an important management goal because of drought experiences. A vegetable farmer said, "Well maintained 
dirt will see you through a season" (\#107). A dairy farmer explained, "The more organic matter you put in the dirt, the better it's going to hold its water" (\#19). While many farmers had always applied organic matter to their soil, some described recent water scarcity experiences as motivating additional efforts to increase soil organic matter. Similarly, while most crop farmers had already been practicing some form of crop rotation and (with forage production) intercropping, most farmers cited drought experiences as a motivator for choosing certain crop rotations (e.g. re-incorporating grain crops into hay and alfalfa rotations) or specific forage species (e.g. planting alfalfa and orchard grass together to increase drought response diversity). Nearly every livestock farmer said that in response to drought they now manage pastures for higher residual dry matter to keep moisture in the soil. Most livestock producers said that they have increased pasture rotation - some increasing rotation frequency and others implementing adaptive multi-paddock grazing plans.

With the expectation that current weather trends would persist and intensify, about half of all respondents had adopted new crops or livestock varieties. Farmers described adding new varieties as offering two primary benefits: spreading the physical risks of extreme weather, while also enabling them to access new market opportunities. This entangled motivation makes sense given that climate change shocks like wildfires, and stressors like persistent drought, are experienced in tandem with market shocks and stressors like tariffs and corporate concentration. When making diversification decisions, some farmers explicitly sought farm enterprises that used less water. One cattle farmer said he added pastured pigs to his operation during the 2012-2014 drought because, "Pigs don't take a lot of water" (\#31). A hay farmer added vegetable seed crops to maintain his income with fewer irrigated acres of higher-value crops. A vegetable farmer described her choice of drought-tolerant crops, like rosemary and dry beans, saying, "You know they say drought places are getting a little drier. It's not like the water is disappearing right? We have a certain amount of water on planet Earth... So maybe I leave the crops that need a lot of water for places that have a lot of water" (\#107). Farmers also described downsizing their operations strategically to allocate the water they did have to the most productive land or their most lucrative enterprises. For example, an orchardist prioritized limited irrigation capacity to high-value fruit trees like cherries, allowing lower-value pear trees to die. Additionally, in response to smoke some farmers reported shifting to faster maturing varieties that could be harvested before late summer fire season.

In response to climate shocks, farmers sometimes implemented coping strategies with the intent to return to their prior practices when the weather changed. During drought years, for example, cattle ranchers sold calves earlier and at lighter weights, changed where and when they grazed, prioritized irrigation water to their best pastures, bought hay they did not have enough water to grow, and reduced their herd size. Ranchers who implemented these reactive coping strategies often expressed their intent to rebuild their herds after destocking in response to drought. One rancher said, "We have no choice. You can't afford to buy feed. And so when we have drought years... we do herd reductions and then you rebuild and you do herd reductions and you rebuild... But it takes a decade or more to rebuild a cow herd, it takes three to four years to rebuild a flock of sheep." Additionally, she explained that returning to prior management is rarely possible because land leases have been irrevocably lost or the timing of calving or calf sales has shifted in an inflexible concentrated market (\#57). Adaptations may begin as temporary and reactive, but often 
these coping strategies became proactive adaptations, even leading to transformation of farm management practices and livelihood strategies, as climate crises (e.g. drought and smoke) and nonclimate crises (e.g. markets and land access) persisted.

Farmers in the Siskiyou region often expanded field management practices they already employed, or adopted new practices grounded in familiar concepts like soil organic matter and water holding capacity. This finding is consistent with previous findings that farmers who already use conservation practices are more likely to increase the scale of those practices (Roesch-McNally, Arbuckle, and Tyndall 2017) and that observation of improvements is itself a significant motivator of adoption (McCann et al. 2015). Yet in this case farmers were also experimenting with novel, even transformative, adaptation practices.

In addition to adopting new field management practices in response to drought and smoke, some respondents also implemented broader livelihood adaptations like seeking long-term off-farm incomes or leaving agriculture altogether. Scholars have long identified flexibility in off-farm employment as an important coping strategy for family farmer persistence (Mooney 1982). The majority of U.S. farm households today are reliant on at least one off-farm income (USDA Census 2017). Yet for many farmers I interviewed, recent compounding crises, particularly water scarcity combined with low market prices for hay or cattle, precipitated a shift in how their families approached off-farm employment. Many farm families had historically viewed off-farm jobs as temporary - working in construction or packing sheds during bad farming years or while raising money to buy land. Recent droughts and wildfire smoke have fueled a shift from understanding off-farm work as a temporary to a more permanent livelihood strategy. In one family that raised cattle, for example, the mother took night classes to become an accountant. She described the goal of this common, and commonly gendered, strategy as, "To diversify your income so [we're] not completely dependent on the weather and the cattle market" (\#54). Another respondent began to cry describing how she and her husband were both looking for permanent off-farm employment, resigning themselves to farming on nights and weekends. She attributed this shift to the previous three years of reduced farm revenue due to low livestock weight gain from wildfire smoke. While these farming families hoped careers off the farm would allow them to continue farming, others adopted the transformational livelihood adaptation (Barnes et al. 2017) of leaving agriculture altogether.

Nearly every farmer and farm advisor described spikes in land sales - both voluntary and forced - during droughts. Like economic crises, drought crises create opportunities for community trauma of debt and dispossession for some, and accumulation for others (Dudley 2000). Multiple farmers interviewed had bought land as neighbors sold their farms during droughts. While foreclosures did occur, few farmers were willing to discuss these openly, preferring to emphasize farmers' agency in farm sales. One mixed livestock farmer reflected that, "You actually saw some people here selling off a lot of cattle and driving a brand new pickup in the peak of the drought. You know, if you're going to cash in your chips... this is a good opportunity for us to walk away" (\#21). Another cattle rancher observed that, for many farmers, recent droughts and wildfires had been, "Come to Jesus moments when people leave their bad relationship with farming" (\#29). 
For many farmers, planning for the future meant focusing on how their children would be able to continue farming. When I asked about climate change beliefs, for example, one multi-species livestock farmer said, "My poor kids. You know, that's why I love what I do is that we're trying to be carbon positive and using animals to do these things. I mean, we really take that into consideration" (\# 21). Another farmer said that as water became scarcer, she was shifting towards "just having event space" (\#115). While these farmers were unique among those in my sample for their willingness to discuss their belief in climate change, their concerns for the future were widely shared. Nearly every farmer shared a hope that the next generation would continue farming and worries that droughts and wildfires - among other factors that make farming hard - would impede that goal.

Across interviewees, farmers were adapting to climate impacts irrespective of how they described weather events and trends, or whether they believed in anthropogenic climate change. In addition to shortterm adaptive measures in response to climate change impacts (Yung et al. 2015; Takahashi, Mano, and Otsuka 2019), I found that farmers in Siskiyou were also implementing a range of long-term adaptive management practices and livelihood strategies in response to climate change impacts, which many expressed an intent to continue into the future, even after the drought or smoke abated. While farmers elsewhere have identified economic factors, like reduced costs and increased efficiency, as the primary motivation for adopting conservation (Burke and Running 2019) and climate mitigation practices (Davidson et al. 2019), I found a deeper core set of motivations. Farmers did want to reduce their water costs, but doing so was not driven solely by a desire to save money (economic rationality) or save water (conservation motivation). Many farmers described a broader motivational orientation in response to confounding crises, predicated on structuring their farming operations so that they could exert more control over their means of production (e.g. water) and make decisions more flexibly and independently (with less state and market intervention) that might enable the next generation to continue farming.

4.4 Public farm advisors reinforce normative climate change beliefs, missing opportunities to support wider climate change action

Public farm advisors often shared and defended the perceptions about climate change that the majority of farmers expressed. County level staff at Farm Service Agency, Natural Resources Conservation Service, Cooperative Extension, Resource Conservation Districts, and County Agriculture Commissioners were reluctant to discuss climate change. When they did, it was often in ways that reinforced dominant farmer ideologies. For example, when asked about climate change, a local Cooperative Extension Advisor responded, "I mean, it's changing, it's constantly changing, it's been changing for millions of years. Farmers have constantly been adapting to that change" (\#25), reinforcing the common assertion by farmers that what they are experiencing is a normal and natural weather cycle that farmers can continue to cope with as they have historically. Another farm advisor said that, "Most farmers would love to see global warming" (\#13), minimizing the negative impacts of climate change and lending legitimacy to scientifically inaccurate narratives of an overall net positive impact of climate change (Takahashi, Mano, and Otsuka 2019). 
Local staff at these institutions consistently reiterated the high degree of weather variability in the region. Multiple service providers asserted that hay, beef, and timber were the only products suitable to the region's harsh climate, despite widespread successful production of diverse crops (including orchard fruits, mixed vegetables, and seed crops) and livestock species (including chickens, pigs, dairy, and small ruminants). These public actors often described farmers who grew crops other than hay or raised livestock other than beef cattle as "hobby farmers," even when these producers identified farming as their primary occupation. Some public farm advisor staff described farmers who rely on off farm income as "not our clientele." Several diversified farmers described their experiences of being dismissed by public institution staff. These examples highlight missed opportunities for institutional actors to help farmers transition towards more diversified practices and strategies in the context of rapidly changing ecological conditions.

Charged with providing farmers with resources and information, public farm advisors are uniquely positioned to aid agricultural responses to climate change (Grantham et al. 2017; Prokopy et al. 2015; Schattman et al. 2018). Across the rural U.S., institutional staff engagement with climate change remains surprisingly limited (Haigh et al. 2015; Grantham et al. 2017). Surveys of farm advisors, for example, have found that many express climate skepticism themselves (Haigh et al. 2015; Arbuckle et al. 2013), are concerned that discussing climate change will alienate the farmers they identify as their clientele (Grantham et al. 2017); and lack resources and confidence to support farmers in responding to climate change (Wiener et al. 2020). Service provider attitudes towards climate programming vary by role and geography. For example, public actors who provide financial planning services are less likely to integrate climate change into their work than advisors who work with farmers on conservation or agronomy (Haigh et al. 2015). In 2017, less than half of Cooperative Extension Advisors in California included climate change in their programming when surveyed (Grantham et al. 2017), whereas farm advisors in Vermont, where climate change belief among farmers is higher, described detailed climate programming in interviews (Schattman et al. 2018). In this study, however, public farm advisors across institutional contexts uniformly expressed they do not discuss climate change with their clientele, do not include explicit climate change adaptation or mitigation in their work, and have no intention of offering climate change programming in the future.

Institutional actors consistently asserted that farmers recognize the weather is changing. A Natural Resources Conservation officer, said, for example, "Ubiquitously people say things aren't how they used to be but won't admit climate change. They recognize the changes but use different vocabulary" (\#37). A state-wide Cooperative Extension Advisor familiar with the region said, "It gets painted with a broad brush that they're conservative and don't believe in climate change, but they've been tracking the weather for a long time and whatever name you put to it, they know it's changing" (\#80). As bridges between farmers and university science, these staff can be important conduits of information (Haigh et al. 2015). The broadly represented assumption is that farmers need climate science information to change their practices, but farm advisors can also help university researchers communicate climate science in more culturally appropriate ways to farmers on the ground, who often identify climate change as a political, not scientific, issue. 
These public actors can also play an important role in shaping farmers' values, beliefs, and norms (Davidson 2016). Sharing values and beliefs can be critical in building trust (Pretty 2003), which is especially important for farmers and advisors to collaborate on topics that are contentious (Inman et al. 2018) or associated with a high degree of uncertainty, like climate change (Schewe and Stuart 2017). But by reflecting the beliefs of the most outspoken farmers, public actors may reinforce a narrow set of acceptable ideas and practices (Pretty 2013), entrenching scientifically inaccurate information (eg. denial of anthropogenic causes), and excluding certain types of farmers (eg. "hobby" farmers). Doing so can inadvertently limit the range of possible responses to climate change and can miss opportunities for public actors to engage farmers in the boundary space between climate science and action.

\subsection{Limitations and future research}

Research on farmers' perceptions and responses related to climate change, as well as inquiries of institutional actors, must be grounded in place. Crisis experiences and change trajectories are embedded within historical, ecological, cultural, political, social, and institutional contexts and can only be understood contextualized within those broader dynamics (Murphy et al. 2017). Place-based empirical research suggests several broad patterns. For example, belief in anthropogenic climate change tends to be higher amongst farmers in the Global South compared than those in the Global North (Madhuri and Sharma 2020; Soubry, Sherren, and Thornton 2020); greater in the northeast U.S. compared to the western U.S. (Schattman, Conner, and Méndez 2016); and higher among women farmers compared to men (Smith et al. 2014; Liu, Smith, and Safi 2014). This is a case study of U.S. crop and livestock farmers in one county in northern California. Though these findings are not generalizable, in combination with those from other empirical studies, they can deepen insights and generate theoretical generalizability and novel approaches to increase the pace and scale of climate action in agricultural contexts. As the logic that beliefs underlie action in a directly corollary begins to crumble, researchers must ask new questions that take farmer perceptions seriously (Soubry et al. 2019). Future research can broaden inquiry by asking, for example, how multiple understandings of climate change affect the pace and scale of adaptation and mitigation; how service providers can more effectively straddle the boundary space not only between both practitioners and research, as well as between local beliefs and climate science. Importantly, new policies and programs that aim to increase the pace and scale of farmers' action on climate change need to ask new questions that no longer assume farmers must be convinced of climate change.

\section{Conclusion And Policy Implications}

Farmers must respond to the effects of climate change, even those who express skepticism of climate science or the culpability of human actions. Madhuri and Sharma (2020) conceptualized farmers' perceptions of climate change as falling into three dimensions: awareness, understanding, and experience. Farmers in this case are aware of climate change and are experiencing its impacts and responding to them. Results of this study suggest that multiple understandings of climate change do not preclude climate action. The fact that crop and livestock farmers in Siskiyou County, California are implementing varied adaptation strategies in response to climate impacts while simultaneously 
expressing skepticism of climate science, adds to mounting evidence that decouples the relationship between climate belief and action (Yung et al. 2015; Schattman, Conner, and Méndez 2016; Davidson et al. 2019; Takahashi, Mano, and Otsuka 2019). These findings suggest that a scientifically correct conceptual understanding of climate change may be less central to urgently needed adaptation action than previously thought.

Research focused on climate change belief as the linchpin of climate action has limited the scope of policies and services (Church et al. 2018) designed to promote climate action. Following early findings that climate belief and action were tightly coupled, programming to encourage climate change adaptation and mitigation in agriculture has largely focused on educating farmers about climate change. Such efforts operate within a knowledge-deficit model, which contrasts knowledgeable experts with ignorant publics in need of information, particularly regarding scientific topics (Jasanoff 2005). Agnostic to embedded power relations and the privileging of certain types of knowledge above others (McNeil 2013), interventions within this framework are often technocratic (Brunk 2006) and rarely effective in changing attitudes or behaviors (Durant et al. 2000).

Educational efforts regarding climate science are laudable, but may be challenging, ineffective, and can even deepen expert-lay divisions (Fricker 2002) and backfire in some situations (Weber 2010). Efforts based on a knowledge-deficit paradigm fail to address structural barriers to change like inequities in resource access (van Huysen, Hansen, and Tall 2018; Calo 2018), or socio-cultural barriers like regional norms (Fish 2014). Interventions that try to convince farmers that climate change is real and humancaused - by agriculture, no less - can exacerbate social risks farmers face related to climate change. Additionally, the outcomes of climate education vary widely by socio-cultural context. Scientific literacy and climate change concerns are correlated among people who identify as liberal, but climate literacy does little to change climate beliefs among conservatives (Kahan et al. 2012); not to mention the wide gap that remains between environmental concern and action across political identities (Barr 2006).

Though I found little evidence that experiences of climate change shifted farmers' belief in its anthropogenic causes, experiences with the physical impacts of climate change did change farmers' actions. Farmers are implementing climate adaptation and mitigation practices irrespective of their skepticism in climate science, suggesting that beliefs about climate change may be beside the point to advancing climate action in working landscapes. Decoupling climate belief and action opens new paradigms of possibility. Leaving belief aside, diverse stakeholders can find common ground by, for example, focusing on impacts instead of causes, and solutions instead of blame.

I am not suggesting that public farm service providers should have free license to spread climate misinformation in efforts to gain farmers' trust. Instead, institutional actors can set belief aside and support farmers in responding to the challenges they face - climate-induced and otherwise. Importantly, as farmers adopt new farming practices and livelihood strategies in response to climate change impacts including engaging in agritourism or permanent off-farm work - farm advisors have an opportunity to support these farmers and explicitly include them in their clientele. Focusing communication on normalcy 
(normal vs. abnormal conditions relative to historic climate) and temporality (temporary vs. permanent changes) may yield more translatable findings (Findlater, Satterfield, and Kandlikar 2019). Campaigns to increase the pace and scale of climate action will likely be more effective if they focus on co-benefits of climate-related practices, particularly how such practices can help farmers re-possess control over their means of production. Recognizing and valuing the stewardship and services farmers already deliver would be a great place to start.

\section{Declarations}

\section{Acknowledgements}

Thank you to the farmers, ranchers, and institutional actors who participated in this study. Thank you also to Nathaniel Tarshish for guidance on finding accessible regional climate data. Thank you to the National Science Foundation Graduate Fellowship Program for funding my time.

\section{Ethical Approval}

This research received university IRB approval (Protocol \#2018-04-11036). Study participants consented to their participation and the publishing of these data.

\section{Funding}

This work was supported by a National Science Foundation Graduate Fellowship Program.

\section{Competing Interests}

The author has no relevant financial or non-financial interests to disclose.

\section{Author Contributions}

The author collected and analyzed all primary data, drafted the manuscript, and approves this final version.

\section{Data Availability}

The primary data employed in this study is qualitative and protected by IRB Protocol \#2018-04-11036.

\section{References}

1. Ajzen, I., 1991. The theory of planned behavior. Organ. Behav. Hum. Decis. Process., Theories of Cognitive Self-Regulation 50, 179-211. https://doi.org/10.1016/0749-5978(91)90020-T

2. Arbuckle, J.G., Morton, L.W., Hobbs, J., 2015. Understanding Farmer Perspectives on Climate Change Adaptation and Mitigation: The Roles of Trust in Sources of Climate Information, Climate Change 
Beliefs, and Perceived Risk. Environ. Behav. 47, 205-234.

https://doi.org/10.1177/0013916513503832

3. Arbuckle, J.G., Prokopy, L.S., Haigh, T., Hobbs, J., Knoot, T., Knutson, C., Loy, A., Mase, A.S., McGuire, J., Morton, L.W., Tyndall, J., Widhalm, M., 2013. Climate change beliefs, concerns, and attitudes toward adaptation and mitigation among farmers in the Midwestern United States. Clim. Change 117, 943-950. https://doi.org/10.1007/s10584-013-0707-6

4. Azadi, Y., Yazdanpanah, M., Mahmoudi, H., 2019. Understanding smallholder farmers' adaptation behaviors through climate change beliefs, risk perception, trust, and psychological distance:

Evidence from wheat growers in Iran. J. Environ. Manage. 250, 109456.

https://doi.org/10.1016/j.jenvman.2019.109456

5. Barnes, M., Bodin, Ö., Guerrero, A., McAllister, R., Alexander, S., Robins, G., 2017. The social structural foundations of adaptation and transformation in social-ecological systems. Ecol. Soc. 22. https://doi.org/10.5751/ES-09769-220416

6. Bedsworth, L., Sumner, D.A., Lee, H., Espinoza, V., Cole, S.A., Bell, A., Davila-Olivera, S., Viers, J., Herman, J., Lund, J., 2018. California's Fourth Climate Change Assessment 97.

7. Breakwell, G.M., 2010. Models of risk construction: some applications to climate change. WIREs Clim. Change 1, 857-870. https://doi.org/10.1002/wcc.74

8. Brunk, C.G., 2006. Public Knowledge, Public Trust: Understanding the 'Knowledge Deficit.' Public Health Genomics 9, 178-183. https://doi.org/10.1159/000092654

9. Burawoy, M., 1998. The Extended Case Method*: Sociol. Theory.

10. Burke, J., Running, K., 2019. Role Identities and Pro-environmental Behavior among Farmers. Hum. Ecol. Rev. 25, 3-22. https://doi.org/10.22459/HER.25.01.2019.01

11. Burke, P.J., Stets, J.E., 2009. Identity Theory. Oxford University Press. https://doi.org/10.1093/acprof:oso/9780195388275.001.0001

12. Buttel, F.H., Newby, H., 1980. Rural sociology of the advanced societies. Allanheld, Osmun.

13. CalFire. URL https://www.fire.ca.gov/media/4jandlhh/top20_acres.pdf (accessed 8.31.21).

14. Calo, A., 2018. How knowledge deficit interventions fail to resolve beginning farmer challenges. Agric. Hum. Values 35, 367-381. https://doi.org/10.1007/s10460-017-9832-6

15. Carrico, A.R., Truelove, H.B., Vandenbergh, M.P., Dana, D., 2015. Does learning about climate change adaptation change support for mitigation? J. Environ. Psychol. 41, 19-29. https://doi.org/10.1016/j.jenvp.2014.10.009

16. Chatrchyan, A.M., Erlebacher, R.C., Chaopricha, N.T., Chan, J., Tobin, D., Allred, S.B., 2017. United States agricultural stakeholder views and decisions on climate change. WIREs Clim. Change 8, e469. https://doi.org/10.1002/wcc.469

17. Chhetri, N., Stuhlmacher, M., Ishtiaque, A., 2019. Nested pathways to adaptation. Environ. Res. Commun. 1, 015001. https://doi.org/10.1088/2515-7620/aaf9f9 
18. Church, S.P., Dunn, M., Babin, N., Mase, A.S., Haigh, T., Prokopy, L.S., 2018. Do advisors perceive climate change as an agricultural risk? An in-depth examination of Midwestern U.S. Ag advisors'

19. views on drought, climate change, and risk management. Agric. Hum. Values 35, 349-365. https://doi.org/10.1007/s10460-017-9827-3

20. Coles, A.R., Scott, C.A., 2009. Vulnerability and adaptation to climate change and variability in semiarid rural southeastern Arizona, USA. Nat. Resour. Forum 33, 297-309.

https://doi.org/10.1111/j.1477-8947.2009.01253.x

21. Coughenour, 2003. Innovating Conservation Agriculture: The Case of No-Till Cropping. Rural Sociol. https://doi.org/10.1111/j.1549-0831.2003.tb00138.x

22. Davenport, S., Leitch, S., 2005. Circuits of Power in Practice: Strategic Ambiguity as Delegation of Authority. Organ. Stud. 26, 1603-1623. https://doi.org/10.1177/0170840605054627

23. Davidson, D., 2016. Gaps in agricultural climate adaptation research. Nat. Clim. Change 6, 433.

24. Davidson, D., Rollins, C., Lefsrud, L., Anders, S., Hamann, A., 2019. Just don't call it climate change: climate-skeptic farmer adoption of climate-mitigative practices. Environ. Res. Lett. 14, 034015. https://doi.org/10.1088/1748-9326/aafa30

25. De Master, K., LaChance, J., Bowen, S., MacNell, L., 2019. Terroir in Transition: Environmental Change in the Wisconsin Artisanal Cheese and New England Oyster Sectors. Sustainability 11, 2969. https://doi.org/10.3390/su11102969

26. Dudley, K.M., 2000. Debt and Dispossession: Farm Loss in America's Heartland. University of Chicago Press.

27. Dunlap, R.E., McCright, A.M., Yarosh, J.H., 2016. The Political Divide on Climate Change: Partisan Polarization Widens in the U.S. Environ. Sci. Policy Sustain. Dev. 58, 4-23. https://doi.org/10.1080/00139157.2016.1208995

28. Durant, J., Bauer, M., Gaskell, G., Midden, C., Liakopoulos, M., Scholten, L., 2000. Two cultures of public understanding of science and technology in Europe, in: Between Understanding and Trust. Routledge.

29. Eisenberg, E.M., 1984. Ambiguity as strategy in organizational communication. Commun. Monogr. 51, 227-242. https://doi.org/10.1080/03637758409390197

30. Findlater, K.M., Kandlikar, M., Satterfield, T., Donner, S.D., 2019a. Weather and Climate Variability May Be Poor Proxies for Climate Change in Farmer Risk Perceptions. Weather Clim. Soc. 11, 697-711. https://doi.org/10.1175/WCAS-D-19-0040.1

31. Findlater, K.M., Satterfield, T., Kandlikar, M., 2019b. Farmers' Risk-Based Decision Making Under Pervasive Uncertainty: Cognitive Thresholds and Hazy Hedging. Risk Anal. Int. J. 39, 1755-1770. https://doi.org/10.1111/risa.13290

32. Findlater, K.M., Satterfield, T., Kandlikar, M., Donner, S.D., 2018. Six languages for a risky climate: how farmers react to weather and climate change. Clim. Change 148, 451-465. https://doi.org/10.1007/s10584-018-2217-z 
33. Fish, R., 2014. Influencing farmers to engage in catchment sensitive farming: An introductory guide to behavioural research for CSFOs and their delivery partners [WWW Document]. URL https://kar.kent.ac.uk/84604/ (accessed 12.9.21).

34. Foguesatto, C.R., Artuzo, F.D., Talamini, E., Machado, J.A.D., 2020. Understanding the divergences between farmer's perception and meteorological records regarding climate change: a review. Environ. Dev. Sustain. 22, 1-16. https://doi.org/10.1007/s10668-018-0193-0

35. Fricker, E., 2002. Elizabeth Fricker, Trusting others in the sciences: a priori or empirical warrant? Stud. Hist. Philos. Sci. Part A 33, 373-383.

36. Geertz, C., 2005. Deep play: notes on the Balinese cockfight. Daedalus 134, 56-86. https://doi.org/10.1162/001152605774431563

37. Gosnell, H., Charnley, S., Stanley, P., 2020. Climate change mitigation as a co-benefit of regenerative ranching: insights from Australia and the United States. Interface Focus 10, 20200027. https://doi.org/10.1098/rsfs.2020.0027

38. Grantham, T., Kearns, F., Kocher, S., Roche, L., Pathak, T., 2017. Building climate change resilience in California through UC Cooperative Extension. Calif. Agric. 71, 197-200.

39. Haden, V.R., Niles, M.T., Lubell, M., Perlman, J., Jackson, L.E., 2012. Global and Local Concerns: What Attitudes and Beliefs Motivate Farmers to Mitigate and Adapt to Climate Change? PLOS ONE 7. https://doi.org/10.1371/journal.pone.0052882

40. Haigh, T., Morton, L.W., Lemos, M.C., Knutson, C., Prokopy, L.S., Lo, Y.J., Angel, J., 2015. Agricultural Advisors as Climate Information Intermediaries: Exploring Differences in Capacity to Communicate Climate. Weather Clim. Soc. 7, 83-93. https://doi.org/10.1175/WCAS-D-14-00015.1

41. Higuera, P.E., Abatzoglou, J.T., 2020. Record-setting climate enabled the extraordinary 2020 fire season in the western United States. Glob. Change Biol. ePub, ePub. https://doi.org/10.1111/gcb.15388

42. Hornsey, M.J., Harris, E.A., Fielding, K.S., 2018. Relationships among conspiratorial beliefs, conservatism and climate scepticism across nations. Nat. Clim. Change 8, 614-620. https://doi.org/10.1038/s41558-018-0157-2

43. Howard, P.H., 2016. Concentration and power in the food system: Who controls what we eat? Bloomsbury Publishing.

44. Hyland, J.J., Jones, D.L., Parkhill, K.A., Barnes, A.P., Williams, A.P., 2016. Farmers' perceptions of climate change: identifying types. Agric. Hum. Values 33, 323-339. https://doi.org/10.1007/s10460015-9608-9

45. Inman, A., Winter, M., Wheeler, R., Vrain, E., Lovett, A., Collins, A., Jones, I., Johnes, P., Cleasby, W., 2018. An exploration of individual, social and material factors influencing water pollution mitigation behaviours within the farming community. Land Use Policy 70, 16-26. https://doi.org/10.1016/j.landusepol.2017.09.042

46. Jasanoff, S., 2003. Technologies of Humility: Citizen Participation in Governing Science. Minerva 41, 223-244. https://doi.org/10.1023/A:1025557512320 
47. Karki, S., Burton, P., Mackey, B., 2020. The experiences and perceptions of farmers about the impacts of climate change and variability on crop production: a review. Clim. Dev. 12, 80-95. https://doi.org/10.1080/17565529.2019.1603096

48. Knapp, C.N., Fernandez-Gimenez, M.E., 2009. Knowledge in Practice: Documenting Rancher Local Knowledge in Northwest Colorado. Rangel. Ecol. Manag. 62, 500-509. https://doi.org/10.2111/08175.1

49. Kremen and Miles, n.d. Ecosystem Services in Biologically Diversified versus Conventional Farming Systems on JSTOR [WWW Document]. URL https://www.jstor.org/stable/26269237\#metadata_info_tab_contents (accessed 9.28.21).

50. Kremen, Merenlender, 2018. Landscapes that work for biodiversity and people. Science 362. https://doi.org/10.1126/science.aau6020

51. Le Dang, H., Li, E., Nuberg, I., Bruwer, J., 2014. Farmers' Perceived Risks of Climate Change and Influencing Factors: A Study in the Mekong Delta, Vietnam. Environ. Manage. 54, 331-345. https://doi.org/10.1007/s00267-014-0299-6

52. Lin, B.B., 2011. Resilience in Agriculture through Crop Diversification: Adaptive Management for Environmental Change. BioScience 61, 183-193. https://doi.org/10.1525/bio.2011.61.3.4

53. Liu, Z., Smith, W.J., Safi, A.S., 2014. Rancher and farmer perceptions of climate change in Nevada, USA. Clim. Change 122, 313-327. https://doi.org/10.1007/s10584-013-0979-x

54. Liverman, D., 2015. Reading climate change and climate governance as political ecologies. Routledge Handb. Polit. Ecol. 303-319.

55. Lobao, L., Meyer, K., 2001. The Great Agricultural Transition: Crisis, Change, and Social Consequences of Twentieth Century US Farming. Annu. Rev. Sociol. 27, 103-124. https://doi.org/10.1146/annurev.soc.27.1.103

56. Madhuri, Sharma, U., 2020. How do farmers perceive climate change? A systematic review. Clim. Change 162, 991-1010. https://doi.org/10.1007/s10584-020-02814-2

57. Marlon, J.R., Linden, S. van der, Howe, P.D., Leiserowitz, A., Woo, S.H.L., Broad, K., 2019. Detecting local environmental change: the role of experience in shaping risk judgments about global warming. J. Risk Res. 22, 936-950. https://doi.org/10.1080/13669877.2018.1430051

58. McCann, L., Gedikoglu, H., Broz, B., Lory, J., Massey, R., 2015. Effects of observability and complexity on farmers' adoption of environmental practices. J. Environ. Plan. Manag. 58, 1346-1362. https://doi.org/10.1080/09640568.2014.924911

59. Mccollum, D.W., Tanaka, J.A., Morgan, J.A., Mitchell, J.E., Fox, W.E., Maczko, K.A., Hidinger, L., Duke, C.S., Kreuter, U.P., 2017. Climate change effects on rangelands and rangeland management: affirming the need for monitoring. Ecosyst. Health Sustain. 3, e01264. https://doi.org/10.1002/ehs2.1264

60. McGuire, J., Morton, L.W., Cast, A.D., 2013. Reconstructing the good farmer identity: shifts in farmer identities and farm management practices to improve water quality. Agric. Hum. Values 30, 57-69. https://doi.org/10.1007/s10460-012-9381-y 
61. McNeil, M., 2013. Between a Rock and a Hard Place: The Deficit Model, the Diffusion Model and Publics in STS. Sci. Cult. 22, 589-608. https://doi.org/10.1080/14636778.2013.764068

62. Menapace, L., Colson, G., Raffaelli, R., 2015. Climate change beliefs and perceptions of agricultural risks: An application of the exchangeability method. Glob. Environ. Change 35, 70-81. https://doi.org/10.1016/j.gloenvcha.2015.07.005

63. Meraner, M., Finger, R., 2019. Risk perceptions, preferences and management strategies: evidence from a case study using German livestock farmers. J. Risk Res. 22, 110-135. https://doi.org/10.1080/13669877.2017.1351476

64. Mooney, P.H., 1982. Labor time, production time and capitalist development in agriculture: A reconsideration of the Mann-Dickinson thesis. Sociol. Rural. 22, 279-292. https://doi.org/10.1111/j.1467-9523.1982.tb01063.x

65. Morton, J.F., 2007. The impact of climate change on smallholder and subsistence agriculture. Proc. Natl. Acad. Sci. 104, 19680-19685.

66. Morton, L.W., McGuire, J.M., Cast, A.D., 2017. A good farmer pays attention to the weather. Clim. Risk Manag., Useful to Usable: Developing Usable Climate Science for Agriculture 15, 18-31. https://doi.org/10.1016/j.crm.2016.09.002

67. Murphy, D.J., Yung, L., Wyborn, C., Williams, D.R., 2017. Rethinking climate change adaptation and place through a situated pathways framework: A case study from the Big Hole Valley, USA. Landsc. Urban Plan. 167, 441-450. https://doi.org/10.1016/j.landurbplan.2017.07.016

68. Nguyen, T.P.L., Seddaiu, G., Virdis, S.G.P., Tidore, C., Pasqui, M., Roggero, P.P., 2016. Perceiving to learn or learning to perceive? Understanding farmers' perceptions and adaptation to climate uncertainties. Agric. Syst. 143, 205-216. https://doi.org/10.1016/j.agsy.2016.01.001

69. Niles, M., Lubell, M., Brown, M., 2015. How limiting factors drive agricultural adaptation to climate change. Coll. Agric. Life Sci. Fac. Publ. 178-185. https://doi.org/10.1016/j.agee.2014.11.010

70. Niles, M., Lubell, M., Haden, V., 2013. Perceptions and responses to climate policy risks among California farmers. Glob. Environ. Change 23, 1752-1760.

https://doi.org/10.1016/j.gloenvcha.2013.08.005

71. Niles, M.T., Mueller, N.D., 2016. Farmer perceptions of climate change: Associations with observed temperature and precipitation trends, irrigation, and climate beliefs. Glob. Environ. Change 39, 133142. https://doi.org/10.1016/j.gloenvcha.2016.05.002

72. Niles, M.T., Wiener, S., Schattman, R.E., Roesch-McNally, G., Reyes, J., 2019. Seeing is not always believing: crop loss and climate change perceptions among farm advisors. Environ. Res. Lett. 14, 044003. https://doi.org/10.1088/1748-9326/aafbb6 NOAA Climate Data. URL https://www.ncdc.noaa.gov/cdo-web/ (accessed 8.31.21).

73. Parker, C., Scott, S., Geddes, A., 2019. Snowball Sampling. SAGE Res. Methods Found.

74. Pathak, T.B., Maskey, M.L., Dahlberg, J.A., Kearns, F., Bali, K.M., Zaccaria, D., 2018. Climate Change Trends and Impacts on California Agriculture: A Detailed Review. Agronomy 8, 25. https://doi.org/10.3390/agronomy8030025

Page 24/31 
75. PDSI. URL https://climatedataguide.ucar.edu/climate-data/palmer-drought-severity-index-pdsi (accessed 8.31.21).

76. Petersen-Rockney, M., Baur, P., Guzman, A., Bender, S.F., Castillo, F., LaChance, J., Mooshammer, M., Ory, J., Price, M.J., Stanley, P., Iles, A., Bowles, T., n.d. Adaptive Capacity Emerges from Diversifying Farming Systems 53.

77. Pretty, J., 2003. Social Capital and the Collective Management of Resources. Science 302, 19121914. https://doi.org/10.1126/science.1090847

78. Price, J., Leviston, Z., 2014. Predicting pro-environmental agricultural practices: The social, psychological and contextual influences on land management. J. Rural Stud. 34, 65-78. https://doi.org/10.1016/j.jrurstud.2013.10.001

79. Prokopy, Linda S., Arbuckle, J.G., Barnes, A.P., Haden, V.R., Hogan, A., Niles, M.T., Tyndall, J., 2015. Farmers and Climate Change: A Cross-National Comparison of Beliefs and Risk Perceptions in HighIncome Countries. Environ. Manage. 56, 492-504. https://doi.org/10.1007/s00267-015-0504-2

80. Prokopy, Linda Stalker, Carlton, J.S., Arbuckle, J.G., Haigh, T., Lemos, M.C., Mase, A.S., Babin, N., Dunn, M., Andresen, J., Angel, J., Hart, C., Power, R., 2015. Extension's role in disseminating information about climate change to agricultural stakeholders in the United States. Clim. Change 130, 261-272. https://doi.org/10.1007/s10584-015-1339-9

81. Prokopy, L.S., Floress, K., Arbuckle, J.G., Church, S.P., Eanes, F.R., Gao, Y., Gramig, B.M., Ranjan, P., Singh, A.S., 2019. Adoption of agricultural conservation practices in the United States: Evidence from 35 years of quantitative literature. J. Soil Water Conserv. 74, 520-534. https://doi.org/10.2489/jswc.74.5.520

82. Prokopy, L.S., Floress, K., Klotthor-Weinkauf, D., Baumgart-Getz, A., 2008. Determinants of agricultural best management practice adoption: Evidence from the literature. J. Soil Water Conserv. 63, 300311. https://doi.org/10.2489/jswc.63.5.300

83. Ranjan, P., Church, S.P., Floress, K., Prokopy, L.S., 2019. Synthesizing Conservation Motivations and Barriers: What Have We Learned from Qualitative Studies of Farmers' Behaviors in the United States? Soc. Nat. Resour. 32, 1171-1199. https://doi.org/10.1080/08941920.2019.1648710

84. Roesch-McNally, G.E., Gordon Arbuckle, J., Tyndall, J.C., 2017. What would farmers do? Adaptation intentions under a Corn Belt climate change scenario. Agric. Hum. Values 34, 333-346. https://doi.org/10.1007/s10460-016-9719-y

85. Rojas-Downing, M.M., Nejadhashemi, A.P., Harrigan, T., Woznicki, S.A., 2017. Climate change and livestock: Impacts, adaptation, and mitigation. Clim. Risk Manag. 16, 145-163. https://doi.org/10.1016/j.crm.2017.02.001

86. Saleh Safi, A., James Smith, W., Liu, Z., 2012. Rural Nevada and Climate Change: Vulnerability, Beliefs, and Risk Perception: Vulnerability and Climate Change. Risk Anal. 32, 1041-1059. https://doi.org/10.1111/j.1539-6924.2012.01836.x

87. Schattman, R.E., Conner, D., Méndez, V.E., 2016. Farmer perceptions of climate change risk and associated on-farm management strategies in Vermont, northeastern United States. Elem. Sci. Anthr. 
4. https://doi.org/10.12952/journal.elementa.000131

88. Schattman, R.E., Roesch-McNally, G., Wiener, S., Niles, M.T., Hollinger, D.Y., 2018. Farm service agency employee intentions to use weather and climate data in professional services. Renew. Agric. Food Syst. 33, 212-221. https://doi.org/10.1017/S1742170517000783

89. Schewe, R.L., Stuart, D., 2017. Why Don't They Just Change? Contract Farming, Informational Influence, and Barriers to Agricultural Climate Change Mitigation. Rural Sociol. 82, 226-262. https://doi.org/10.1111/ruso.12122

90. Shukla et al, 2019. IPCC, 2019: Climate Change and Land: an IPCC special report on climate change, desertification, land degradation, sustainable land management, food security, and greenhouse gas fluxes in terrestrial ecosystems. URL https://www.ipcc.ch/srccl/chapter/summary-for-policymakers/ (accessed 11.9.20).

91. Singh, A.S., Eanes, F., Prokopy, L.S., 2020. Climate change uncertainty among American farmers: an examination of multi-dimensional uncertainty and attitudes towards agricultural adaptation to climate change. Clim. Change 162, 1047-1064. https://doi.org/10.1007/s10584-020-02860-w

92. Smith, W.J., Liu, Z., Safi, A.S., Chief, K., 2014. Climate change perception, observation and policy support in rural Nevada: A comparative analysis of Native Americans, non-native ranchers and farmers and mainstream America. Environ. Sci. Policy 42, 101-122.

https://doi.org/10.1016/j.envsci.2014.03.007

93. Soubry, B., Sherren, K., Thornton, T.F., 2020. Are we taking farmers seriously? A review of the literature on farmer perceptions and climate change, 2007-2018. J. Rural Stud. 74, 210-222. https://doi.org/10.1016/j.jurstud.2019.09.005

94. Stanley, P.L., Rowntree, J.E., Beede, D.K., DeLonge, M.S., Hamm, M.W., 2018. Impacts of soil carbon sequestration on life cycle greenhouse gas emissions in Midwestern USA beef finishing systems. Agric. Syst. 162, 249-258. https://doi.org/10.1016/j.agsy.2018.02.003

95. Stuart, D., Schewe, R.L., McDermott, M., 2012. Responding to Climate Change: Barriers to Reflexive Modernization in U.S. Agriculture. Organ. Environ. 25, 308-327. https://doi.org/10.1177/1086026612456536

96. Sulewski, P., Kłoczko-Gajewska, A., 2014. Farmers' risk perception, risk aversion and strategies to cope with production risk: an empirical study from Poland. Stud. Agric. Econ. 116, 140-147. https://doi.org/10.7896/j.1414

97. Takahashi, B., Burnham, M., Terracina-Hartman, C., Sopchak, A.R., Selfa, T., 2016. Climate Change Perceptions of NY State Farmers: The Role of Risk Perceptions and Adaptive Capacity. Environ. Manage. 58, 946-957. https://doi.org/10.1007/s00267-016-0742-y

98. Takahashi, K., Mano, Y., Otsuka, K., 2019. Learning from experts and peer farmers about rice production: Experimental evidence from Cote d'Ivoire. World Dev. 122, 157-169. https://doi.org/10.1016/j.worlddev.2019.05.004

99. Thornberg and Charmaz, 2013. Grounded Theory and Theoretical Coding in: The SAGE Handbook of Qualitative Data Analysis. SAGE. 
100. USDA Census, 2017. USDA Census Full Report [WWW Document]. URL https://www.nass.usda.gov/Publications/AgCensus/2017/index.php\#full_report (accessed 5.20.20).

101. van Huysen, T., Hansen, J., Tall, A., 2018. Scaling up climate services for smallholder farmers: Learning from practice. Clim. Risk Manag., Scaling Up Climate Services for Smallholder Farmers: Learning from Practice 22, 1-3. https://doi.org/10.1016/j.crm.2018.10.002

102. Walker, R., 2004. The Conquest of Bread: 150 Years of California Agribusiness. New Press 270, 8494.

103. Weber, E.U., 2010. What shapes perceptions of climate change? WIREs Clim. Change 1, 332-342. https://doi.org/10.1002/wcc.41

104. White, S.S., Selfa, T., 2013. Shifting Lands: Exploring Kansas Farmer Decision-Making in an Era of Climate Change and Biofuels Production. Environ. Manage. 51, 379-391. https://doi.org/10.1007/s00267-012-9991-6

105. Wiener, S., Roesch-McNally, G.E., Schattman, R.E., Niles, M.T., 2020. Ready, willing, and able? USDA field staff as climate advisors. J. Soil Water Conserv. 75, 62-74. https://doi.org/10.2489/jswc.75.1.62

106. Wojcik, D.J., Monroe, M.C., Adams, D.C., Plate, R.R., 2014. Message in a Bottleneck? Attitudes and Perceptions of Climate Change in the Cooperative Extension Service in the Southeastern United States. J. Hum. Sci. Ext. 2.

107. Wyborn, C., Yung, L., Murphy, D., Williams, D.R., 2015. Situating adaptation: how governance challenges and perceptions of uncertainty influence adaptation in the Rocky Mountains. Reg. Environ. Change 15, 669-682. https://doi.org/10.1007/s10113-014-0663-3

108. Yung, L., Belsky, J.M., 2007. Private Property Rights and Community Goods: Negotiating Landowner Cooperation Amid Changing Ownership on the Rocky Mountain Front. Soc. Nat. Resour. 20, 689703. https://doi.org/10.1080/08941920701216586

109. Yung, L., Phear, N., DuPont, A., Montag, J., Murphy, D., 2015. Drought Adaptation and Climate Change Beliefs among Working Ranchers in Montana. Weather Clim. Soc. 7, 281-293. https://doi.org/10.1175/WCAS-D-14-00039.1

\section{Figures}




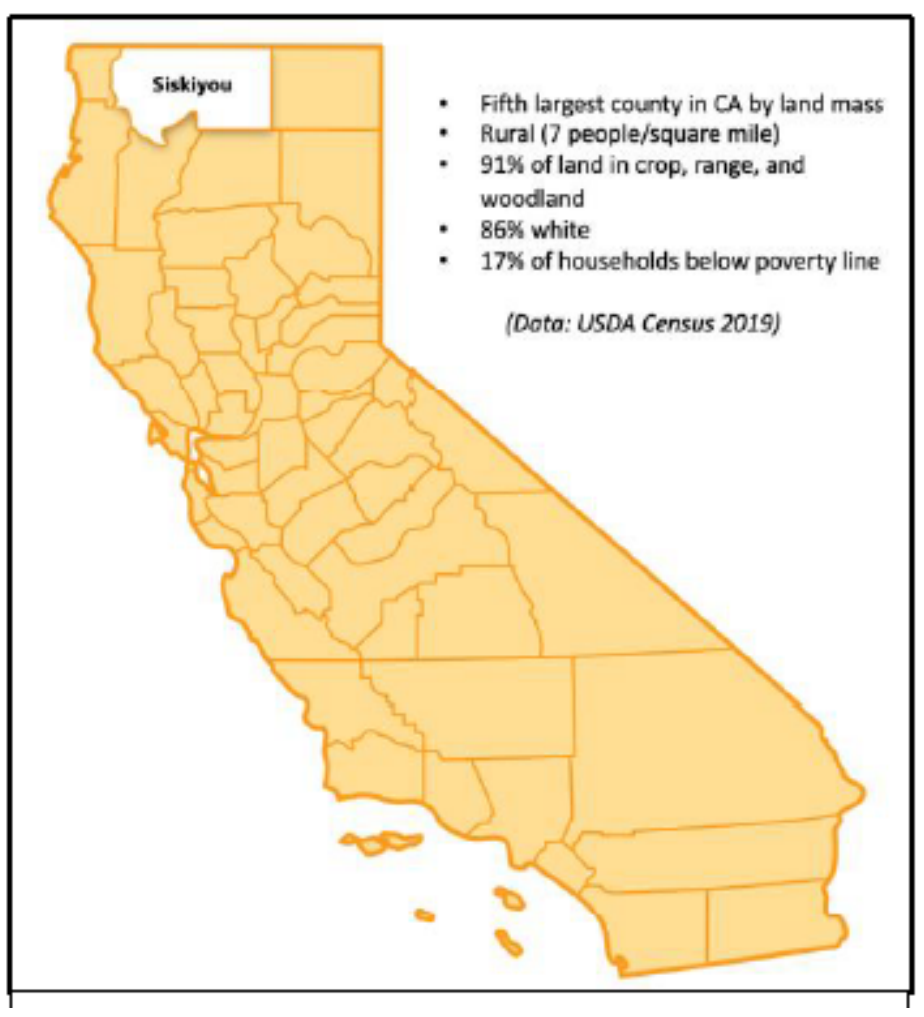

Figure 1

Map and characteristics of Siskiyou County, California 

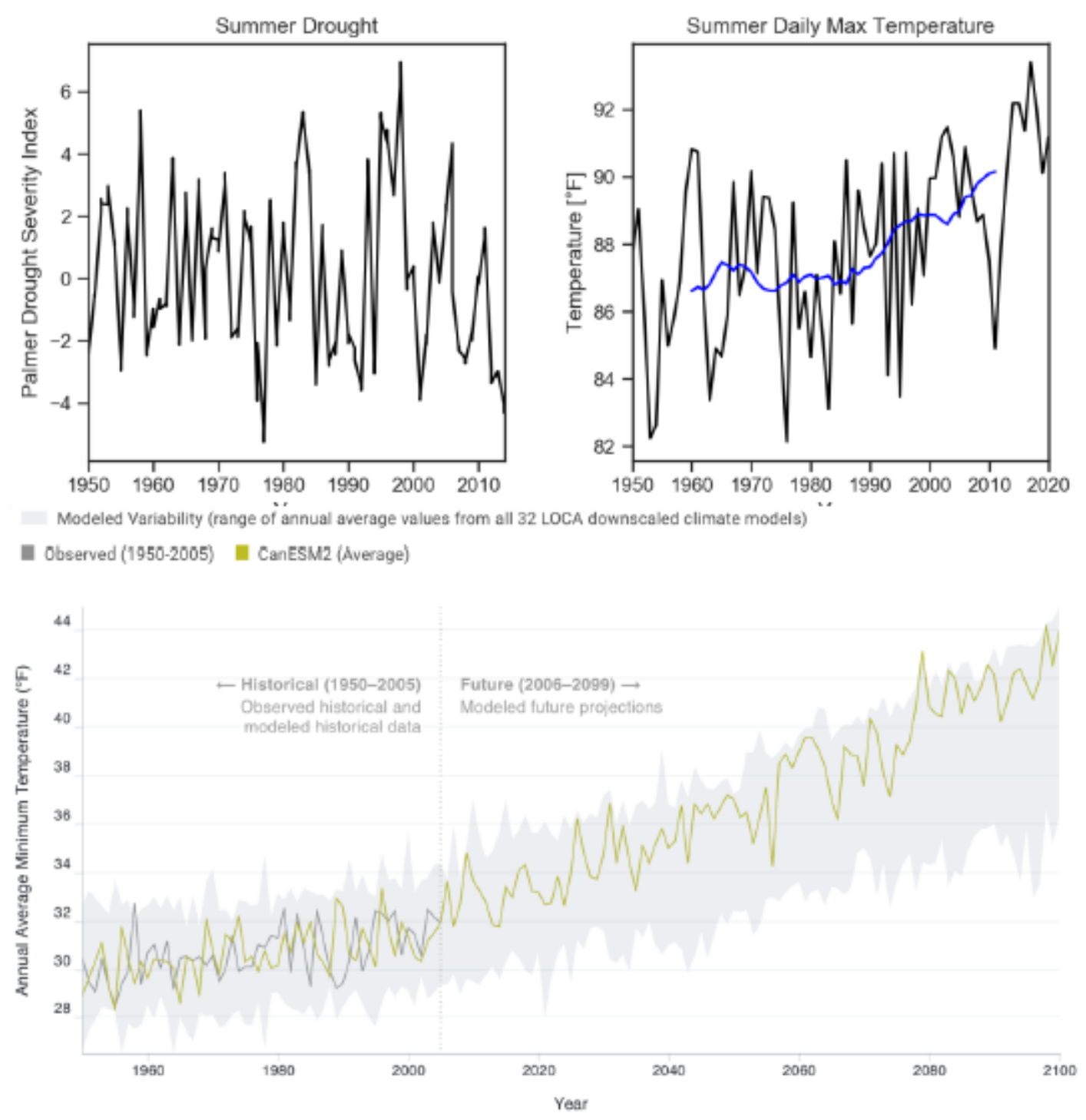

Figure 2

Palmer Drought Severity Index (left) for summers in Siskiyou County from 1950-2015, note high degree of drought volatility. Summer daily maximum temperatures from 1950-2020, note the high degree of noise (black line) with subtle climate signals emerging (blue line, the 20-year rolling centered average). The drought index represents a regional average over a 2.5 degree $\times 2.5$ degree domain centered on $(41.25$, -121.25). The summer average of the daily max temperature data was taken from the Yreka weather station and was downloaded from the NOAA Climate Data center on August 30, 2021. Annual average minimum temperature in Siskiyou County (bottom), observed 1950-2020 (gray line) and modeled (green line) using an average simulation (CanESM2) in an optimistic scenario (RCP 4.5) in which emissions peak around 2040, then decline. Source: Cal-Adapt. Data: LOCA Downscaled Climate Projections (Scripps Institution of Oceanography), Gridded Historical Observed Meteorological Data (University of Colorado, Boulder). 


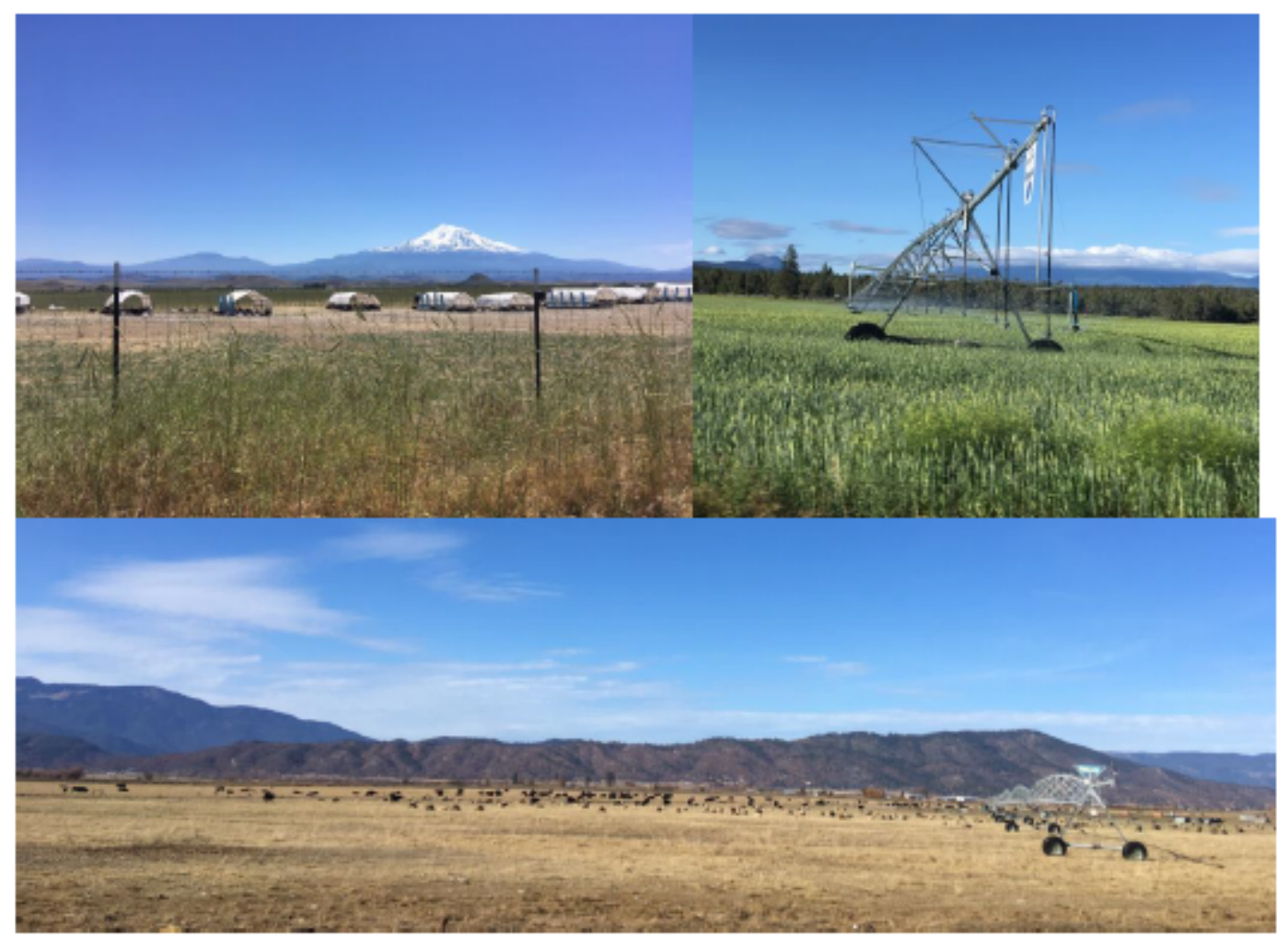

\section{Figure 3}

Farmers reported diversifying strategies that improve soil moisture holding capacity and create new market opportunities (e.g. integrating pastured poultry with beef and hay production, left image). Farmers were also investing in irrigation infrastructure like deeper wells and pivots with LESA nozzles (right image). Many farmers described the region's harsh geography and cycles of drought - the bottom image captures the high desert landscape of much of the region, beef cattle grazing, and an irrigation pivot.

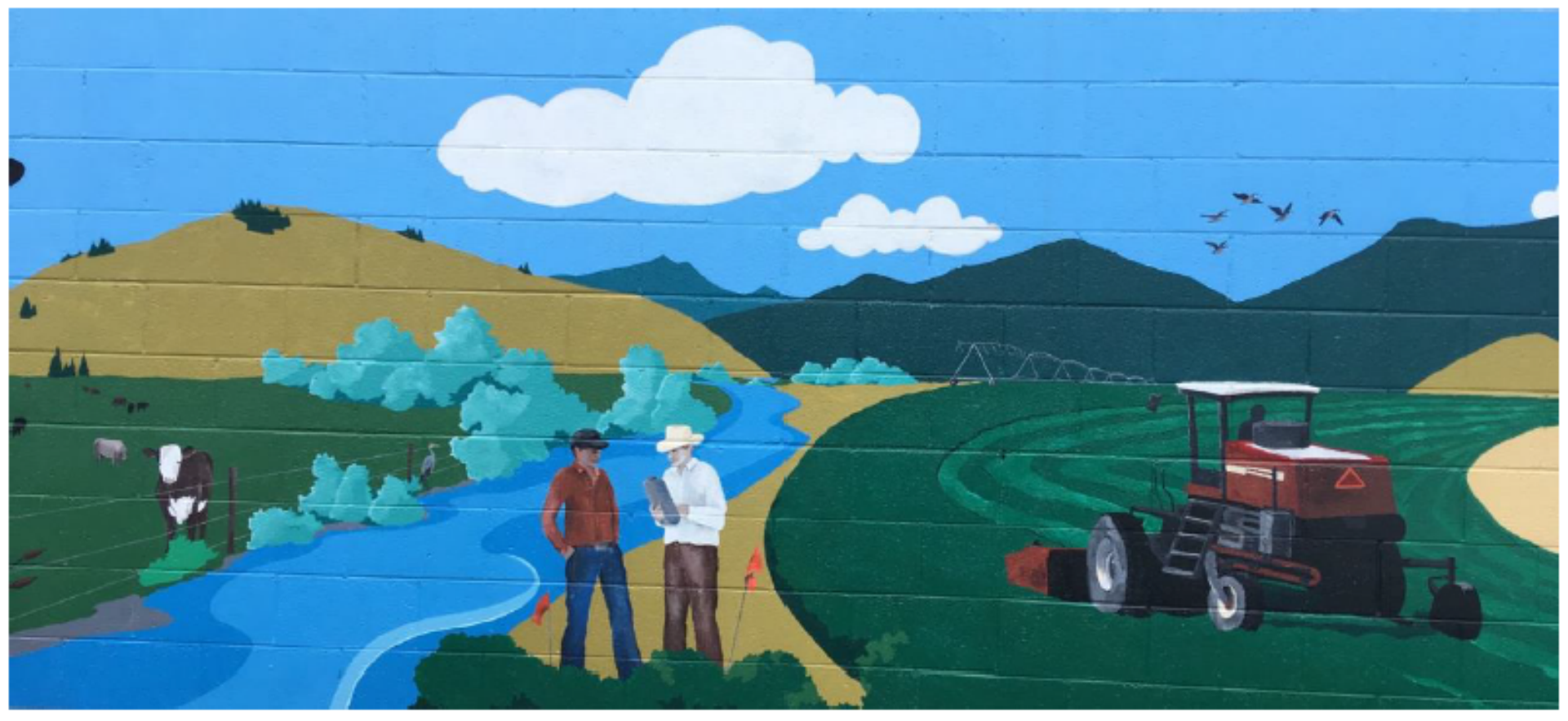


Figure 4

Mural painted on the local Cooperative Extension building. Note that irrigated cattle pasture and alfalfa fields are pictured. 